\title{
Industrial Growth and Dynamic Externalities: the Case of Sweden
}

\author{
Rasha Gustavsson (formerly Torstensson) \\ Lund University
}

\begin{abstract}
This study examines the relevance of various theories of knowledge spillovers and growth using a data set on geographic concentration, diversity and competition in 24 counties in Sweden between 1977 and 1996. The results suggest that local competition as opposed to urban variety and regional specialization seems to encourage employment growth. Thus, the evidence is largely consistent with parts of the hypotheses proposed by Porter and Jacobs, but the MAR theory does not receive empirical support based on the evidence presented in the present study.
\end{abstract}

- JEL Classifications: O50, R10

- Key words: Dynamic externalities, Industrial growth, Specialization, Competition, Diversity

\section{Introduction}

Some historians, e.g. Jacobs (1969) and Bairoch (1988), claimed that most innovations are made in cities. The basic intuition behind the claim is that the concentration of individuals, occupations and industries provides an environment, which facilitates the flow of ideas. Interactions between people in cities, thus, help individuals get ideas and innovate. In consequence, individuals are willing to pay high rents to work in cities, since they have the opportunity to learn from others and thus improve their own productivity. This easy flow of ideas may be an

*Corresponding address: Professor Rasha Gustavsson (formerly Torstensson), Department of Economics, Lund University, Box 7082, S-220 07 LUND, Sweden Tel: +46-46-222 8673 Fax: +46-46-222 4118 Email: Rasha.Gustavsson@NEK.LU.SE

(C2003-Center for International Economics, Sejong Institution, All Rights Reserved. 
explanation to why cities survive despite the high rents. ${ }^{1}$

This dynamic view of cities fits nicely with economic growth theories, which view externalities associated with knowledge spillovers as the "engine of growth" (Romer (1986) and Lucas (1988)). If we accept the notion that geographical proximity enhances the flow of ideas, then it becomes more apparent why we would expect knowledge transfer to be particularly important in cities, (Glaeser et. al. 1992).

Earlier industrial location literature assumes that firms change location in response to changes in the current comparative advantage offered by different locations. ${ }^{2}$ The pattern of location of firms in an industry would, thus, depend upon factors such as wages, population, industrial composition, utility prices and tax rates of these different locations. A recently growing literature assumes instead that the existing location of firms in a particular industry is strongly affected by "history", particularly the historical industrial environment of cities. ${ }^{3}$ Historical conditions, thus, determine the intangibles of today's economic environment. For example, the local stock of knowledge and the availability of labor force with specific skills. These intangible factors cannot be directly measured however their historical determinants can. Consequently, the location of firms and industry employment today can be determined.

Accordingly, in the present study I examine the predictions of various theories of knowledge spillovers and growth using detailed industrial statistics for the largest industries across all twenty-four regions in Sweden. ${ }^{4}$ This is instructive since earlier empirical studies have focused on the case of the United States. In this regard a comparison between the Swedish case and the American case might offer new insights into the understanding of the empirical applicability of theories of dynamic externalities and growth.

Thus the paper relies largely on Glaeser et al. (1992) but uses Swedish data. As such, the main contribution of the paper is the constructed data set and the comparative analysis of the Swedish and the US evidence. The basic finding is

\footnotetext{
${ }^{1}$ Other scholars have also argued that the reason why cities survive despite the high rents is due to the differences in tastes and preferences, rather than differences in productivity.

${ }^{2}$ For a review see Herzong and Schlottman (1991)

${ }^{3}$ See Glaeser, Kallal, Scheinkman and Schlefer (1992), Henderson, Kuncoro and Turmer (1992), Miracky (1992), and Henderson (1994).
}

${ }^{4}$ This new data set was constructed for the purpose of this study. 
that, in the Swedish case, local competition seems to be positively correlated with employment growth. Moreover, the evidence is inconclusive with regards to how urban variety and regional specialization affect growth.

The division of the study is as follows, in Section two I explore some of the leading theories of dynamic externalities and growth. Section three offers a summary of the main empirical findings. In Sections four and five the data and methodology employed in this study are explained. The results and some comparisons with earlier empirical findings are explored in Sections six and seven. Finally Section eight offers some concluding remarks.

\section{Theories of Dynamic Externalities and Empirical Results}

Higher productivity growth in cities compared to other regions is generally explained endogenously by knowledge spillovers. These spillovers are in turn facilitated by geographical proximity. There are three bench mark theories for this kind of knowledge spillovers namely: the Marshall-Arrow-Romer (MAR) theory, Porter's theory and Jacobs' theory. Following Glaeser et al. the three theories analyze technological externalities, whereby innovations and improvements occurring in one firm enhance the productivity of the other firms without full compensation.

The MAR theory considers knowledge spillovers between firms in the same industry. ${ }^{5}$ Marshall (1890) applied this view where the basic intuition is that industrial concentration in a city facilitates knowledge spillovers between firms. Consequently, the industry in question would experience productivity growth translated into higher city growth. The MAR theory predicts that local monopoly is better for growth than local competition. ${ }^{6}$ This is because monopoly allows externalities to be internalized by the innovator and restricts the flow of knowledge to others. Thus, the MAR externalities are maximized in cities with geographically specialized industries, where local monopoly dominates.

Porter (1990), as MAR, argues that knowledge spillovers in specialized geographically concentrated industries enhance growth. Nevertheless, in his view local competition, as opposed to local monopoly, stimulates new innovations and facilitates their adoption. Thus, Porter's externalities are maximized in cities with

${ }^{5}$ For an early formalization see Arrow (1962). See also Romer (1986).

${ }^{6}$ This is also predicted by Schumpeter (1942) 
geographically specialized competitive industries.

Contrary to MAR and Porter, Jacobs (1969) argues that the most important knowledge transfers come from outside the core industry. Consequently, variety and diversity of geographically proximate industries, not geographically specialized industries, enhance innovation and in turn promote growth. Like Porter Jacobs favors local competition over local monopoly. All three theories of dynamic externalities are very useful in the sense that they attempt to explain simultaneously how cities form and why they grow.

To sum up, models of city growth stress the role of dynamic externalities and more specifically knowledge spillovers for city growth. Accordingly cities grow because people in cities interact with other people, either in their own or in other sectors and learn from them. The basic difference between these theories is twofold; first they differ in whether knowledge spillovers come from within the industry or from other industries. Second they differ in their predictions of how local competition affects the impact of these knowledge spillovers on growth.

Both MAR and Porter agree that the most important technology externalities occur within industries, and that regional specialization is good for growth both for the specialized industries and for the cities they are in. However MAR would argue that local monopoly is good because it allows internalization of externalities. In contrast Porter would argue that local competition is good because it fosters imitation and innovation. As for Jacobs, the idea is that the crucial externality in cities is cross-fertilization of ideas across different lines of work, and like Porter Jacobs favors local competition because it stimulates innovation.

Although these theories have some differences, nevertheless, they all have implications for growth of industries in certain cities. This is what distinguishes these theories from the standard location and urbanization theories that instead deal with the formation and specialization of cities but not city growth e.g. Henderson (1986). The following sub-section briefly outlines the basic ideas behind theories of localization and urbanization. ${ }^{7}$

\footnotetext{
${ }^{7}$ Although not directly relevant to the present study it may be instructive to conclude this section with a note on the so-called localization and urbanization static externalities. These static externalities explain how natural resources or transport advantage may determine the location of industries. They in turn contribute to specialization but not to growth. This is especially important for high-fixed-cost industries. There are also arguments against urbanization externalities. When an industry in a city grows it increases wages and rents and so makes it more expensive for other industries to expand in the city, this is referred to as crowding. Conversely, when an industry in a city shrinks it frees up land and labor and makes growth of other industries more attractive.
} 
In this section we will explore some of the more important empirical results. There have been a few empirical tests of the three theories of dynamic externalities. Glaeser et al. (1992) examine the predictions of the various theories of knowledge spillovers and growth using data on geographic concentration and competition of industries in 170 of the largest US cities. They chose the largest industries since one of the strongest implications of growth models is that externalities in these models are sources of permanent income growth. If, it is the case that these externalities are in fact permanent and important then one would expect to observe them in the largest industries. If, on the other hand, externalities are important only early in an industry's life cycle and disappear after an industry matures then they would not be picked up empirically, and this implies that they are not sources of permanent growth.

The first question asked by Glaeser et al. is which industries in which cities have grown fastest between 1956 and 1987 and why. Bearing in mind that the three theories of dynamic externalities differ in what they believe the source of externalities is and what makes their capture more effective. Testing empirically in which cities industries grow faster as a function of geographic specialization and competition would shed some light on which externalities if any are important for growth.

The empirical findings derived by Glaeser et al. is based on a cross section of city industries (e.g., New York apparel and textiles, Philadelphia apparel and textiles, Philadelphia electrical equipment). This facilitates tracing knowledge spillovers compared to if one were investigating whole cities. The first finding is that industries, measured by employment, grow slower in cities where they are over represented. This finding does not favor the local within-industry externality theory of MAR and Porter, according to which industries should grow faster in places where they are over represented. In addition, they also find that industries grow faster in cities where firms in those industries are smaller than the national average size of firms in that particular industry. If we take the view that spreading the same employment over more firms increases local competition between firms and therefore the spread of knowledge, then this result would support Porter's and Jacob's view that local competition is growth promoting. On the other hand, one could take the view that smaller firms grow faster, however, this is not completely compatible with the MAR model or with other evidence. Lastly they find that cityindustries grow faster when the rest of the city is less specialized. This result supports Jacobs's view that city diversity promoted growth as knowledge spills 
over industries. To summarize the empirical evidence found in this study does not support the MAR model, is mixed on Porter and is consistent with Jacobs.

One may wonder why are so many cities specialized in few industries if MAR externalities are not so important (at least in the previous empirical investigation they are not). The answer is that there are many other externalities not accounted for by theories of dynamic externalities that may explain regional specialization and city formation. These externalities do not consider knowledge spillovers and growth. Marshall (1980), for example, has argued that firms in the same industry often locate next to each other to share various inputs. ${ }^{8}$ Moreover, Henderson (1986) presents empirical evidence indicating that output per labor-hour is higher in firms that have other firms from the same industry located nearby. Static localization externalities can thus easily account for city specialization, but not for growth.

In addition, Henderson (1986) explained so-called "urbanization" externalities which explains why firms may chose to locate in places where demand is high. These models tend to predict that firms in different industries tend to locate next to each other, which suggests that they do not offer the complete story of city formation. Lichtenberg (1960), Murphy, Schleifer and Vishny (1989), and Krugman (1991a, 1991b) have presented models of such externalities. Urbanization externalities and localization externalities, thus, explain patterns of industry location rather than growth. Moreover, Wheat (1986) finds strong evidence that manufacturing employment grows faster in regions with more rapid population growth. Glaeser et al. also presented some evidence pointing toward the importance of urbanization externalities.

In Henderson (1994) additional empirical evidence on the role of dynamic externalities for individual industries is provided. In particular, the role of externalities from own industries (localization, or MAR externalities) as opposed to the role of externalities from overall diversity of the local environment (urbanization, or Jacobs externalities) is examined. Henderson employs panel data that allows to separate dynamic effects from fixed effects. Panel data analysis also provides evidence as to how long history matters. Two basic issues are tested, first whether firms learn primarily from other firms within an industry or from firms outside the industry, and second whether externalities of whatever type are primarily static or dynamic. Henderson uses an eleven-year panel for 1977-1987 of data on country employment levels in different 2-digit manufacturing industries.

${ }^{8}$ Other externalities are disscused by Lichtenberg (1960), Henderson (1986,1988), Arthur (1989), and Rotenberg and Saloner (1990). 
The basic finding derived by Henderson is that the maintenance of strength in a particular industry requires concentrations of employment in that industry and a surrounding diverse industrial base. Diversity, thus, tends to raise productivity and hence employment in a city's particular concentration activity. Moreover, the evidence suggests that both localization and urbanization effects are important. In other words there is evidence of both MAR and Jacobs externalities. For traditional industries most effects die out after four or five years, but for high tech industries effects can persist longer, that is history does matter according to Henderson (1993).

Jaffe et al. (1993) analyze the extent to which externalities are static or dynamic. Their work suggests that industry specific information diffuse slowly over space, so that access to that knowledge binds firms to the same location over time, however, this geographical localization fades away overtime. A larger scale of own industry activity historically means that firms today in a particular location will operate with greater intangibles, such as accumulated knowledge ${ }^{9}$ than otherwise. Moreover, the social information network of a certain location matters in facilitating communications and information spillovers among local firms.

From the above it is apparent that the existing tests have focused on the case of the US which, although instructive, is by no means general. Thus, more empirical tests of the various theories based on other case studies would be informative. In light of the above two issues can be empirically investigated. First, we can study whether there are differences in the relevance of the various theories of static and dynamic externalities based on country differences, and to what factors such differences could be attributed.

\section{Arriving to the Reduced Form}

The three theories of dynamic externalities, following Glaeser et al., can be combined in an economic model from which the reduced form can be derived. Assume that each firm in an industry at a given location takes technology, prices and wages as given and maximizes the following function:

$$
A_{t} f_{t}\left(l_{t}\right)-w_{t} l_{t}
$$

Where $A_{t}$ is technology measured nominally, ${ }^{10}$ is the basic production function,

\footnotetext{
${ }^{9}$ About technology, sources of supply of different quantity inputs, etc.

${ }^{10}$ Such that changes in $A$ represent changes in technology and in prices.
} 
$l_{t}$ is labor input, and $w_{t}$ is wages at time $t .{ }^{11}$ Each firm thus sets the labor input to equate the marginal product of labor to it's wage:

$$
A_{t} f^{\prime}\left(l_{t}\right)=w_{t}
$$

Rewriting (2) in terms of growth rates gives:

$$
\log \left(\frac{A_{t+1}}{A_{t}}\right)=\log \left(\frac{w_{t+1}}{w_{t}}\right)-\log \left[\frac{f^{\prime}\left(l_{t+1}\right)}{f^{\prime}\left(l_{t}\right)}\right]
$$

The level of technology $A_{t}$ in a city-industry is assumed to have both national and local components such that:

$$
A=A_{\text {local }} A_{\text {natinal }}
$$

The growth rate will thus be the sum of the growth of national and local technology in this industry such that.

$$
\log \left(\frac{A_{t+1}}{A_{t}}\right)=\log \left(\frac{A_{\text {local }, t+1}}{A_{\text {local }, t}}\right)+\log \left(\frac{A_{\text {natilnal }, t+1}}{A_{\text {national }, t}}\right)
$$

Growth in national technology is assumed to capture the changes in the price of the products as well as shifts in nationwide technology in the industry. Local technology is assumed to grow at a rate exogenous to the firm but dependent on the various technological externalities present in this industry in this city, that is:

$$
\log \left(\frac{A_{\text {local }, t+1}}{A_{\text {local }, t}}\right)=g(\text { specialization, localmonopoly, diversity, initialconditions })+e_{t+1}
$$

Where specialization is a measure of concentration of a particular industry within a city, which according to MAR and Porter is supposed to raise the rate of technological progress. Local monopoly is a measure of appropriability of innovation, which raises technological progress according to MAR and reduces it according to Porter; and diversity measures the variety of activities that the city pursues, which according to Jacobs speeds up technological progress. Initial values of wages and employment are included because it has been argued that firms move to low-wage areas, and because high initial values of employment may reduce employment growth.

If we set $f(l)=l^{1-\alpha}, 0<\alpha<1$, then (3), (5), and (6) can be combined to obtain:

\footnotetext{
${ }^{11}$ Since the production function abstracts from capital inputs, and allows only for labor input, that means that labor-saving technology will not be captured.
} 


$$
\begin{gathered}
\alpha \log \left(\frac{l_{t+1}}{l_{t}}\right)=-\log \left(\frac{w_{t+1}}{w_{t}}\right)+\log \left(\frac{A_{\text {national }, t+1}}{A_{\text {national }, t}}\right)+g(\text { specialization, competition, } \\
\text { diversity, initial conditions })+e_{t+1}
\end{gathered}
$$

Growth in nationwide employment is assumed to capture changes in nationwide technology and prices. Workers are assumed to participate in a nationwide labor market so that the wage growth will just be the same across city-industries. Equation (7) thus allows us to associate the growth of employment in an industry in a city with the measures of technological externalities given by the theories. ${ }^{12}$

\section{Data and Variable Description}

\section{A. The Data}

The data set was constructed from 1977 and 1996 editions produced by Swedish Statistical Bureau (SCB). 1977 and 1996 were the first and last years respectively for which comprehensive industrial statistics on a regional level was available. ${ }^{13}$

Three basic variables on employment, payroll and number of establishments by two-digit industry for every region in Sweden (a total of 24 regions) are utilized for the construction of the various proxies employed in the regression analysis. ${ }^{14}$

\section{B. Variable Description}

Following Glaeser et al. (1992) in the choice of variables and methodology, A Swedish data set was constructed and linear regressions are thereafter run ${ }^{15}$. The variables are described below:

\section{The Results}

The results of the initial regressions are reported in Table 1, where the seven

\footnotetext{
${ }^{12}$ The specification of (7) assumes that knowledge spillovers are constant over time, which a is basic restriction of the model.

${ }^{13}$ It ought to be noted that the period chosen is a rather special one for Sweden (as well as other countries) in terms of technological progress, I will return to this issue when discussing the results.

${ }^{14}$ The data employed is regional as opposed to city data.

${ }^{15}$ There is no a priori reason to expect non-linearity thus the choice of linear regression analysis.
} 


\section{Table 1}

\begin{tabular}{l}
$\begin{array}{l}\text { 1. Growth in regional industry employment measured as: Growth in Regional industry mploy- } \\
\text { ment measured as: log (employment in 1996/employment in 1977) in the regional industry. }\end{array}$ \\
\hline $\begin{array}{l}\text { 2. Growth in national industry employment measured as: log (employment in 1996/employ- } \\
\text { ment 1977) in the industry outside the region. }\end{array}$ \\
\hline $\begin{array}{l}\text { 3. Wages in the regional industry in } 1977 \text { in thousands of SEK per year, measured as: (payroll } \\
\text { in 1977/employment in 1977). }\end{array}$ \\
\hline 4. Regional industry employment in 1977. \\
\hline $\begin{array}{l}\text { 5. Specialization measured as: regional industry's share of regional employment relative to } \\
\text { National industry's share of National employment in 1977. }\end{array}$ \\
\hline $\begin{array}{l}\text { 6. Competition measured as: establishment per employee in the regional industry relative to } \\
\text { establishment per employee in the industry nationwide in 1977. }\end{array}$ \\
\hline $\begin{array}{l}\text { 7. Diversity measured as : the region's other top five industries share of 1977 total regional } \\
\text { employment. }\end{array}$ \\
\hline $\begin{array}{l}\text { 8. Growth in regional industry wages measured as: log (wage in 1996/wage in 1977) in the } \\
\text { regional industry. }\end{array}$ \\
\hline $\begin{array}{l}\text { 9. Growth in national industry wages measured as: log (national wage in 1996/national wage } \\
\text { 1977) in the industry outside the region. }\end{array}$ \\
\hline 10. Wage in the region in 1987. \\
\hline
\end{tabular}

largest industries in all 24 Swedish counties are included making a total of 168 observations. As control variables log employment in 1977 and log wages in 1977 both of can be regarded as initial conditions. Moreover, it has been argued that firms move to low wage regions, or that laborers move to high wage areas, thus the wage variable controls for this effect. Terkla and Doeringer (1991) and Blanchard and Katz (1992) suggest that changes in demand for a regions output are the principal determinants of employment growth in that region. Consequently, in order to correct for such demand shifts national employment growth in the industry is included as an explanatory variable.

The externality variables, i.e. specialization, competition and diversity are included separately in columns (i), (ii), and (iii) respectively. In column (iv) all three externality variables are included at the same time.

The results suggest that initial employment and wages, or the initial conditions, are not significant. Growth in national employment, as may be expected, is significant at the $1 \%$ level and is quantitatively high varying between 1.015 and 0.986. Of the three externalities only Competition seems to affect industry growth and is significant at the $10 \%$ level when included separately in column (ii) and 
Table 2. Regression Results

Dependent Variable Regional Industry Employment Growth between 1977-1996 for the seven largest industries

\begin{tabular}{|l|l|l|l|l|}
\hline \multicolumn{1}{|c|}{ Variables } & (i) & (ii) & (iii) & (iv) \\
\hline \multirow{3}{*}{ Constant } & 0.185 & 0.034 & 0.184 & 0.079 \\
& $(0.51)$ & $(0.09)$ & $(0.49)$ & $(0.22)$ \\
& {$[0.61]$} & {$[0.92]$} & {$[0.62]$} & {$[0.82]$} \\
\hline \multirow{3}{*}{ Log employment 77 } & 0.020 & 0.063 & 0.019 & 0.058 \\
& $(0.37)$ & $(1.18)$ & $(0.33)$ & $(1.02)$ \\
& {$[0.71]$} & {$[0.24]$} & {$[0.74]$} & {$[0.31]$} \\
\hline & -0.150 & -0.186 & -0.146 & -0.183 \\
Log wage 77 & $(-0.63)$ & $(-0.81)$ & $(-0.58)$ & $(-0.77)$ \\
& {$[0.53]$} & {$[0.42]$} & {$[0.56]$} & {$[0.44]$} \\
\hline \multirow{2}{*}{ National employment } & 1.013 & 0.986 & 1.011 & 1.015 \\
Growth in the industry & $(8.03)^{* * *}$ & $(8.52)^{* * *}$ & $(8.12)^{* * *}$ & $(8.34)^{* * *}$ \\
& {$[0.00]$} & {$[0.00]$} & {$[0.00]$} & {$[0.00]$} \\
\hline \multirow{3}{*}{ Specialization } & 0.001 & & & 0.006 \\
& $(0.12)$ & & & $(1.12)$ \\
\hline \multirow{2}{*}{ Competition } & {$[0.91]$} & & & {$[0.26]$} \\
& & 0.062 & & 0.071 \\
& & $(1.6)^{*}$ & & $(1.71)^{*}$ \\
Diversity & & {$[0.10]$} & & {$[0.09]$} \\
\hline OBS. & & & -0.008 & -0.067 \\
\hline $\bar{R}^{2}$ & 168 & 168 & $(-0.04)$ & $(-0.33)$ \\
\hline
\end{tabular}

Note: parenthesis ( ) give heteroscedasticity consistent $t$-statistics, and [ ] give p-values. $*=$ significant at the $10 \%$ level $* *=$ significant at the $5 \%$ level, and $* * *=$ significant at the $1 \%$ level.

when included together with specialization and diversity, in column (iv). However, specialization and diversity do not seem to explain regional industry employment growth. The coefficient for competition varies between $0.06-0.07$ this suggests that doubling the number of firms per worker compared to the national average leads to between 6-7\% increase regional employment over a period of twenty years.

To interpret the results taking the theoretical background as a point of departure requires a brief recapitulation of the three theories of dynamic externalities. As mentioned above both MAR and Porter share the view that regional specialization is good for growth. Nevertheless, MAR argues, contrary to Porter and Jacobs who prefers local competition, that local monopoly is good because it internalizes 
Table 3. Regression Results Dependent

Variable Regional Industry Wage Growth between 1977-1996, for the six largest industries

\begin{tabular}{|c|c|c|c|c|}
\hline Variables & (i) & (ii) & (iii) & (iv) \\
\hline Constant & $\begin{array}{l}2.021 \\
(3.06)^{* * * *} \\
{[0.00]}\end{array}$ & $\begin{array}{l}2.139 \\
(3.17)^{* * * *} \\
{[0.00]}\end{array}$ & $\begin{array}{l}2.039 \\
(2.99)^{* * *} \\
{[0.003]}\end{array}$ & $\begin{array}{l}2.133 \\
(3.21)^{* * * *} \\
{[0.001]}\end{array}$ \\
\hline Log employment 77 & $\begin{array}{l}-0.023 \\
(-0.99) \\
{[0.32]}\end{array}$ & $\begin{array}{l}-0.046 \\
(-1.46) \\
{[0.14]}\end{array}$ & $\begin{array}{l}-0.019 \\
(-0.75) \\
{[0.45]}\end{array}$ & $\begin{array}{l}-0.042 \\
(-1.41) \\
{[0.16]}\end{array}$ \\
\hline Log wage 77 & $\begin{array}{l}-0.862 \\
(-2.08)^{* *} \\
{[0.04]}\end{array}$ & $\begin{array}{l}-0.849 \\
(-2.19)^{* *} \\
{[0.028]}\end{array}$ & $\begin{array}{l}-0.862 \\
(-2.06)^{* *} \\
{[0.04]}\end{array}$ & $\begin{array}{l}-0.873 \\
(-2.23)^{* *} \\
{[0.02]}\end{array}$ \\
\hline $\begin{array}{l}\text { National wage growth } \\
\text { in the industry }\end{array}$ & $\begin{array}{l}0.464 \\
(0.99) \\
{[0.32]}\end{array}$ & $\begin{array}{l}0.449 \\
(1.05) \\
{[0.29]}\end{array}$ & $\begin{array}{l}0.413 \\
(0.91) \\
{[0.36]}\end{array}$ & $\begin{array}{l}0.446 \\
(1.01) \\
{[0.31]}\end{array}$ \\
\hline Specialization & $\begin{array}{l}0.005 \\
(1.37) \\
{[0.17]}\end{array}$ & & & $\begin{array}{l}0.003 \\
(0.77) \\
{[0.44]}\end{array}$ \\
\hline Competition & & $\begin{array}{l}-0.047 \\
(-1.17) \\
{[0.24]}\end{array}$ & & $\begin{array}{l}-0.044 \\
(-1.07) \\
{[0.28]}\end{array}$ \\
\hline Diversity & & & $\begin{array}{l}0.008 \\
(0.09) \\
{[0.93]}\end{array}$ & $\begin{array}{l}0.049 \\
(0.46) \\
{[0.64]}\end{array}$ \\
\hline$O B S$. & 144 & 144 & 144 & 144 \\
\hline $\bar{R}^{2}$ & 0.13 & 0.15 & 0.13 & 0.14 \\
\hline
\end{tabular}

Note: parenthesis ( ) give heteroscedasticity consistent $t$-statistics, and [ ] give p-values. ${ }^{*}=$ significant at the $10 \%$ level $* *=$ significant at the $5 \%$ level, and $* * *=$ significant at the $1 \%$ level.

externalities. Finally, Jacobs claims that the crucial externality in cities is crossfertilization of ideas across different industries, and like Porter Jacobs favors local competition because it stimulates innovation.

Thus, the MAR theory was not supported by the above evidence, however, neither was it rejected. In particular, in equations (i) and (iv) the coefficient for the specialization variable was not significant in either case suggesting that the evidence is inconclusive. Neither did Jacobs claim that the variety of neighboring industries enhances growth receive conclusive support. In both equations (iii) and (iv) the variable measuring diversity was insignificant. However, Jacobs' and Porter's suggestion that more firms per worker in a city-industry compared with the national average, or competition, would lead to higher growth seems to receive empirical support. The evidence from equations (ii) and (iv) reveals that the 
competition variable is positive and significant and is, thus, consistent with both Porter's and Jacobs' theories of dynamic externalities. ${ }^{16}$

Following Glaeser et al. I have, thus far, measured industry growth using employment growth a better measure is naturally productivity growth. However, since output is non-observable it is difficult to measure productivity. On the other hand, it is plausible that a rough measure of productivity growth may be cityindustry wage growth, assuming that some of the productivity gains accrues to labor. The same procedure described above is employed here, i.e. the three externalities are included separately in the first three columns and in the last regression all three are included. The results are presented in Table 3 below.

From the Table above some basic observations can be made, to begin with only the logarithm of wages in 1977 seems to matter for the growth in regional industry wages between 1977 and 1996. Moreover, none of the three dynamic externalities seems to affect regional industry wage growth although some weak evidence is found for specialization. Finally neither the logarithm for employment nor national wage growth in the industry seems to matter for regional industry wage growth, or at the very least the evidence is inconclusive.

There is more than one explanation for the week evidence presented above. To begin with the measure used here to proxy productivity growth is not compatible with the model of national labor markets presented above. In addition, since productivity growth only accrues partially to labor measuring it with growth in wages is rather imperfect. ${ }^{17}$ Nevertheless since I took Glaeser et al. as my point of departure the basic aim has been to compare their results with the ones derived here on Swedish data. Consequently despite the problems associated with the cityindustry wage growth measure I thought it would be informative to run these regressions on the Swedish data.

Due to the reliance on proxy variables specification tests are called for. Therefore I performed the Ramsey (1969) test of omitted variables and the null hypothesis of no contemporaneous correlation could not be rejected at the $5 \%$ level. The interpretation being that omitted variables need not be an important problem in the

\footnotetext{
${ }^{16}$ The very same regressions were run employing the largest six, instead of the largest seven. As might be expected the results were upheld when using the largest six instead of seven industries. The variables that seem to matter for industry growth, measured by employment growth are growth in national employment and competition. Thus the results are still consistent with parts of Porters and Jacobs' hypothesis.

${ }^{17}$ Additional discussion can be found in Glaeser et al. (1992).
} 
analysis. I have also conducted a normality test according to Shapiro and Wilk (1965), and the hypothesis of normality could not be rejected at the 5\% level. Suggesting that the OLS estimations are consistent and efficient. Needless to say that despite these tests the results ought to be considered with caution. ${ }^{18}$

\section{Swedish versus American Industrial Growth: An Appraisal}

Prior to further discussion some relevant potential concerns to the results need to be pointed out. There are two basic reservations that can be of relevance for both this study and Glaeser et al. To begin with, the fact that the production function does not allow us to capture labor saving technological innovations, and that the dependent variable measures growth in employment at a period where labor-saving technological progress is certainly actual. The second reservation is the inclusion of the initial employment values, making the model specification seem more like an endogenous growth model as implied by the inclusion, this in turn makes inferences about location questionable.

Having stated this let us now look more carefully at the Swedish as compared to the American results bearing in mind the above mentioned reservations. In the American case competition and urban variety seemed to explain employment growth in industries within metropolitan areas. Whereas in the Swedish case only competition seemed to explain employment growth in industries in Swedish regions. The fact that local competition is the most important dynamic externality in Sweden can be attributed to the fact that Swedish industries have for a long time been regulated. At least in relative terms the Swedish industrial environment is less competitive compared to the American. This can be attributed to various factors among which protection and militant labor unions in Sweden are certainly accountable. Nonetheless, the evidence suggests that competition is important even in the American case, that is indicative of the importance of this type of externality in general for industrial growth.

The evidence does not necessarily suggest that urban variety and regional specialization are not important in Sweden, they may very well be but not to the same extent as local competition. From the evidence presented in this study the variables capturing urban variety and regional specialization turn out insignificant or inconclusive. Compared to the American case where urban variety as suggested by Jacobs enhances industrial growth. One may thus conclude that urban variety is

\footnotetext{
${ }^{18}$ Diagnostic testing have a rather low power and are thus difficult to reject.
} 
more important in the US than it is in Sweden. This in turn may be attributed to differences in the nature of industrial dispersion in the two countries, which in turn is a consequence of very different geographical characteristics and economic sizes of Sweden compared to the US.

A basic distinction to which some econometric complications may be attributed is the distinction between dynamic and static externalities. The latter is by definition continuos while the former is static. Thus, the lack of robust econometric results might be due to the fact that dynamic effects at least in some cases are only temporary; i.e. change from one level to the other. In which case their effect could not be captured by the specified estimation. ${ }^{19}$ According to the reduced form estimated, the specification assumes that the proxies for dynamic externalities are flow variables. Thus, any temporary changes from one level to the other would not be captured and rendered statistically insignificant coefficients.

The reliance on proxy variables in the econometric estimations represents an additional problem. Unfortunately it is not uncommon to rely on surrogate variables or so-called proxy variables in econometric estimations. This is due to the fact that some variables are very difficult to quantify especially intangible variables such as those employed in the present study. Naturally this may be argued as a weakness, nevertheless, it is by all means not a weakness that makes the estimations inconsistent only inefficient. Thus, some caution is recommended when drawing conclusions based on estimations that make use of proxy variables.

Furthermore, worth noting is that the differences in the results may partially be attributed to the choice of time periods which are different in the two studies. In Glaeser et al. the time period employed was 1956-1987, whereas in the present study I employ $1977-1996^{20}$. In particular, the time period employed for Sweden case is characterized by relevant developments. To begin with, technological development combined with a slow productivity trend in Swedish industries during that period led to reduced employment in virtually all industries. Secondly the deregulation of Swedish industries which coincided with this period are also expected to affect the results. In the latter case, however, we would expect deregulation to bias the results in the opposite direction making competition less important and or insignificant. In

\footnotetext{
${ }^{19}(7) \alpha \log \left(\frac{l_{t+1}}{l_{t}}\right)=-\log \left(\frac{w_{t+1}}{w_{t}}\right)+\log \left(\frac{A_{\text {national }, t+1}}{A_{\text {national }, t}}\right)+g($ specialization, competition, diversity, initial conditions) $+e_{t-1}$

${ }^{20}$ For which regional industrial data was available.
} 
other words, the fact that competition seems to be the only important externality for industrial growth in Sweden, despite deregulation, implies that further deregulation may be important for industrial growth in the Swedish case.

Thus, if we were to draw policy implications based on the Swedish evidence it would be a policy which aims at deregulation of Swedish industries. Since local competition is the only statistically significant variable explaining industrial growth then it is fair to draw the conclusion that policies aimed at enhanced local competition are most likely to be growth promoting.

\section{Concluding Remarks}

In general we can conclude, with some reservation, that the relevance of the three theories of dynamic externalities does vary according to country differences. This in turn may be explained by the differences in the economic environments of different countries. In particular, comparing the US case with the Swedish case gave interesting insights in this regard. Whereas in the American case local competition and urban variety could explain employment growth in industries, in the Swedish case local competition appeared to be the most important for industry growth. The explanation to the above is two fold, on the one hand there are differences associated with the geographical natures of the American compared to the Swedish economies, on the other hand there may econometric concerns due to the reliance on proxy variables.

This study by all means suggests the need for further empirical research to add to our understanding of how theories of dynamic externalities work in practice. In this regard additional country studies of a similar nature to this one would be instructive. Secondly, it would be interesting to see whether the theories are more or less relevant for different industries. Whether for example Jacob's theory is more applicable for the car industry as compared with the computer industry which in turn may better be explained by the MAR theory. Furthermore, the construction of new variables and data sets on the industry level would by all means facilitate further research in this relatively new area.

Received May 2002, Accepted 17 February 2003

\section{References}

Arrow, K. J., (1962), “The Economic Implications of Learning by Doing”, Review of 
Economics Studies, 29, 155-73.

Arthur, W. B. (1989), "Silicon Valley Locational Clusters: When Do Increasing Returns Imply Monopoly?", working paper, Santa Fe, N.M., Santa Fe Institution.

Bairoch, P. (1988), Cities and Economic Development: From the Dawn of History to the Present, Chicago: Chicago University Press.

Blanchard O. J. and L. F. Katz, (1992), "regional Evolutions", Brookings Papers Econ. Activity, no.1.

Glaeser E. L., H. D. Kallal, J. A. Scheinkman and A. Schleifer, (1992), "Growth in Cities", Journal of Political Economy, 100(6), 1126- 1152.

Henderson, J. V. (1986), "Efficiency of Resource Usage and City Size", Journal of Urban Economics, 19, 47-70.

Henderson, J. V. (1988), Urban Development: Theory, Fact, and Illusion, New York: Oxford University Press.

Henderson, J. V. (1994), "Externalities and Industrial Development", NBER Working Paper No. 4730.

Henderson, J. V. A. Kuncoroand and M. Turmer, (1992), "Industrial Development in Cities", NBER Working Paper No. 4178.

Herzog, H. W. and A. M. Schlottman, (1991), (eds.), Industrial Location and Public Policy, Knoxville: University of Tennessee Press.

Jacobs, J. (1969), The Economy of Cities, New York: Vintage.

Jaffe, A. B. M. Trajtenberg and R. Hendersson, (1993), "Geographical Localization of knowledge spillovers as evidenced by Patent Citations", Quarterly Journal of Economics, 577-598.

Krugman, P. (1991a), "Cities in Space: Three Simple Models", Manuscript, Cambridge: MIT.

Krugman, P. (1991b), "Increasing Returns and Economic Geography", Journal of Political Economy, 99, 483-99.

Lichtenberg, R. M. (1960), One-Tenth of a Nation: National Forces in the Economic Growth of the New York Region, Cambridge, Mass.: Harvard University Press.

Lucas, R. E., Jr. (1988), "On the Mechanics of economic Development", Journal of Monetary Economics, 22, 3-42

Marshall, A., (1890), Principles of Economics, London: Macmillan.

Miracky, W. F. (1992), "Technological Spillovers, the Product cycle and Regional Growth", MIT mimeo.

Murphy, Shleifer and Vishny.

Porter, M. E. (1990), The Competitive Advantage of Nations. New York: Free Press.

Ramsey, J.B. (1969), "Tests for Specification Errors in Classical Linear Least Squares Regression Analysis", Journal of The Royal Statistics Society, Series B, 31, 350-371.

Romer, P. M. (1986), "Increasing Returns and Long-Run Growth", Journal of Political Economy, 94, 1002-37.

Rotemberg J. and G. Saloner, (1990), "Competition and Human Capital Accumulation: A theory of Interregional

Shapiro, S. S. and Wilk, M. B. (1965). "An Analysis of Variance Test for Normality", 
Biometrika 52(4), 591-611.

Specialization and Trade, Manuscript, Cambridge MIT.

Schumpeter, J. A. (1942), Capitalism, Socialism, and democracy, New York: Harper.

Wheat, L. F. (1986), “The Determinants of 1963-77 Regional Manufacturing Growth:

Why the South and West Grow", Journal of Regional Science, 26, 635-59.

Terkla, D. G. and P. B. Doeringer, (1991), "Explaining Variations in Employment Growth: Structural and Cyclical Change among States and Local Areas", Journal of Urban Economics, 29, 329-48.

\section{Appendix I}

Table I. Summary Statistics

\begin{tabular}{llrrrr}
\hline \multicolumn{1}{c}{ Series } & Obs & \multicolumn{1}{c}{ Mean } & \multicolumn{1}{c}{ Std Error } & \multicolumn{1}{c}{ Minimum } & \multicolumn{1}{c}{ Maximum } \\
\hline CEMPLGROWTH & 168 & -0.173931 & 0.222708 & -1.104198 & 0.468355 \\
NEMPLGROWTH & 168 & -0.150643 & 0.120957 & -0.656469 & 0.043731 \\
LOGWAGE77 & 168 & 1.851316 & 0.053449 & 1.532283 & 2.028048 \\
LOGEMPL77 & 168 & 3.498876 & 0.384960 & 2.133539 & 4.528788 \\
CWAGES77 & 168 & 71.522127 & 8.363579 & 34.062970 & 106.671390 \\
CITYEMPL77 & 168 & 4460.321429 & 4253.316238 & 136.000000 & 33790.000000 \\
SPECIALIZATION77 & 168 & 1.574063 & 1.651847 & 0.253778 & 19.211183 \\
COMPETITION77 & 168 & 1.028106 & 0.527404 & 0.098120 & 2.968896 \\
DIVERSITY77 & 168 & 0.708170 & 0.084157 & 0.460485 & 0.878340 \\
CWAGEGROWTH & 168 & 0.660339 & 0.252501 & -0.176177 & 2.614496 \\
NWAGEGROWTH & 168 & 0.630489 & 0.017179 & 0.606379 & 0.685096 \\
\hline
\end{tabular}

\section{Appendix II}

Table II. a. Largest Regional Industries in 1977 (Sweden)

\begin{tabular}{llc}
\hline \multicolumn{1}{c}{ Region } & \multicolumn{1}{c}{ Industry } & Employment \\
\hline 1 Älvsborgs & Transport Equipment (vehicles, ships, Aerospace, other) & 33,790 \\
2 Stockholm & Electric and optical equipment & 26,236 \\
3 Skaraborgs & Textiles, wearing apparel, fur and leather & 18,258 \\
4 Stockholm & Pulp, paper, paper products, publishing, printing and & 16,161 \\
& reproduction of recorded media & \\
5 Hallands & Food, beverages and tobacco & 13,338 \\
6 Skaraborgs & Transport Equipment (vehicles, ships, Aerospace, other) & 12,465 \\
7 Kopparbers & Electric and optical equipment & 11,291 \\
8 Västerbottens & Basic metals & 11,126 \\
9 Stockholm & Transport Equipment (vehicles, ships, Aerospace, other) & 10,426 \\
10 Västermanslands & Machinery & 10,284 \\
\hline
\end{tabular}


Table II. b. Most Common Regional Industries (Sweden)

\begin{tabular}{lc}
\hline \multicolumn{1}{c}{ Industry } & Number of Appearances in Sample \\
\hline Fabricated metal products & 22 \\
Machinery & 22 \\
Pulp, paper, paper products, publishing, printing and & 21 \\
reproduction of recorded media & \\
Food, beverages and tobacco & 17 \\
Wood and cork & 15 \\
Transport equipment & 12 \\
Basic metals & 10 \\
Coke, refined petroleum products \& nuclear feul, & 8 \\
Chemical \& chemical products & \\
Electronic machinery, electronic equipment Medical & 7 \\
precision \& optical instruments, watches clocks & \\
Non-metallic mineral products (stone, clay, \& glass) & 5 \\
\hline
\end{tabular}




\title{
Industrial Growth and Dynamic Externalities: the Case of Sweden
}

\author{
Rasha Gustavsson (formerly Torstensson) \\ Lund University
}

\begin{abstract}
This study examines the relevance of various theories of knowledge spillovers and growth using a data set on geographic concentration, diversity and competition in 24 counties in Sweden between 1977 and 1996. The results suggest that local competition as opposed to urban variety and regional specialization seems to encourage employment growth. Thus, the evidence is largely consistent with parts of the hypotheses proposed by Porter and Jacobs, but the MAR theory does not receive empirical support based on the evidence presented in the present study.
\end{abstract}

- JEL Classifications: O50, R10

- Key words: Dynamic externalities, Industrial growth, Specialization, Competition, Diversity

\section{Introduction}

Some historians, e.g. Jacobs (1969) and Bairoch (1988), claimed that most innovations are made in cities. The basic intuition behind the claim is that the concentration of individuals, occupations and industries provides an environment, which facilitates the flow of ideas. Interactions between people in cities, thus, help individuals get ideas and innovate. In consequence, individuals are willing to pay high rents to work in cities, since they have the opportunity to learn from others and thus improve their own productivity. This easy flow of ideas may be an

*Corresponding address: Professor Rasha Gustavsson (formerly Torstensson), Department of Economics, Lund University, Box 7082, S-220 07 LUND, Sweden Tel: +46-46-222 8673 Fax: +46-46-222 4118 Email: Rasha.Gustavsson@NEK.LU.SE

(C2003-Center for International Economics, Sejong Institution, All Rights Reserved. 
explanation to why cities survive despite the high rents. ${ }^{1}$

This dynamic view of cities fits nicely with economic growth theories, which view externalities associated with knowledge spillovers as the "engine of growth" (Romer (1986) and Lucas (1988)). If we accept the notion that geographical proximity enhances the flow of ideas, then it becomes more apparent why we would expect knowledge transfer to be particularly important in cities, (Glaeser et. al. 1992).

Earlier industrial location literature assumes that firms change location in response to changes in the current comparative advantage offered by different locations. ${ }^{2}$ The pattern of location of firms in an industry would, thus, depend upon factors such as wages, population, industrial composition, utility prices and tax rates of these different locations. A recently growing literature assumes instead that the existing location of firms in a particular industry is strongly affected by "history", particularly the historical industrial environment of cities. ${ }^{3}$ Historical conditions, thus, determine the intangibles of today's economic environment. For example, the local stock of knowledge and the availability of labor force with specific skills. These intangible factors cannot be directly measured however their historical determinants can. Consequently, the location of firms and industry employment today can be determined.

Accordingly, in the present study I examine the predictions of various theories of knowledge spillovers and growth using detailed industrial statistics for the largest industries across all twenty-four regions in Sweden. ${ }^{4}$ This is instructive since earlier empirical studies have focused on the case of the United States. In this regard a comparison between the Swedish case and the American case might offer new insights into the understanding of the empirical applicability of theories of dynamic externalities and growth.

Thus the paper relies largely on Glaeser et al. (1992) but uses Swedish data. As such, the main contribution of the paper is the constructed data set and the comparative analysis of the Swedish and the US evidence. The basic finding is

\footnotetext{
${ }^{1}$ Other scholars have also argued that the reason why cities survive despite the high rents is due to the differences in tastes and preferences, rather than differences in productivity.

${ }^{2}$ For a review see Herzong and Schlottman (1991)

${ }^{3}$ See Glaeser, Kallal, Scheinkman and Schlefer (1992), Henderson, Kuncoro and Turmer (1992), Miracky (1992), and Henderson (1994).
}

${ }^{4}$ This new data set was constructed for the purpose of this study. 
that, in the Swedish case, local competition seems to be positively correlated with employment growth. Moreover, the evidence is inconclusive with regards to how urban variety and regional specialization affect growth.

The division of the study is as follows, in Section two I explore some of the leading theories of dynamic externalities and growth. Section three offers a summary of the main empirical findings. In Sections four and five the data and methodology employed in this study are explained. The results and some comparisons with earlier empirical findings are explored in Sections six and seven. Finally Section eight offers some concluding remarks.

\section{Theories of Dynamic Externalities and Empirical Results}

Higher productivity growth in cities compared to other regions is generally explained endogenously by knowledge spillovers. These spillovers are in turn facilitated by geographical proximity. There are three bench mark theories for this kind of knowledge spillovers namely: the Marshall-Arrow-Romer (MAR) theory, Porter's theory and Jacobs' theory. Following Glaeser et al. the three theories analyze technological externalities, whereby innovations and improvements occurring in one firm enhance the productivity of the other firms without full compensation.

The MAR theory considers knowledge spillovers between firms in the same industry. ${ }^{5}$ Marshall (1890) applied this view where the basic intuition is that industrial concentration in a city facilitates knowledge spillovers between firms. Consequently, the industry in question would experience productivity growth translated into higher city growth. The MAR theory predicts that local monopoly is better for growth than local competition. ${ }^{6}$ This is because monopoly allows externalities to be internalized by the innovator and restricts the flow of knowledge to others. Thus, the MAR externalities are maximized in cities with geographically specialized industries, where local monopoly dominates.

Porter (1990), as MAR, argues that knowledge spillovers in specialized geographically concentrated industries enhance growth. Nevertheless, in his view local competition, as opposed to local monopoly, stimulates new innovations and facilitates their adoption. Thus, Porter's externalities are maximized in cities with

${ }^{5}$ For an early formalization see Arrow (1962). See also Romer (1986).

${ }^{6}$ This is also predicted by Schumpeter (1942) 
geographically specialized competitive industries.

Contrary to MAR and Porter, Jacobs (1969) argues that the most important knowledge transfers come from outside the core industry. Consequently, variety and diversity of geographically proximate industries, not geographically specialized industries, enhance innovation and in turn promote growth. Like Porter Jacobs favors local competition over local monopoly. All three theories of dynamic externalities are very useful in the sense that they attempt to explain simultaneously how cities form and why they grow.

To sum up, models of city growth stress the role of dynamic externalities and more specifically knowledge spillovers for city growth. Accordingly cities grow because people in cities interact with other people, either in their own or in other sectors and learn from them. The basic difference between these theories is twofold; first they differ in whether knowledge spillovers come from within the industry or from other industries. Second they differ in their predictions of how local competition affects the impact of these knowledge spillovers on growth.

Both MAR and Porter agree that the most important technology externalities occur within industries, and that regional specialization is good for growth both for the specialized industries and for the cities they are in. However MAR would argue that local monopoly is good because it allows internalization of externalities. In contrast Porter would argue that local competition is good because it fosters imitation and innovation. As for Jacobs, the idea is that the crucial externality in cities is cross-fertilization of ideas across different lines of work, and like Porter Jacobs favors local competition because it stimulates innovation.

Although these theories have some differences, nevertheless, they all have implications for growth of industries in certain cities. This is what distinguishes these theories from the standard location and urbanization theories that instead deal with the formation and specialization of cities but not city growth e.g. Henderson (1986). The following sub-section briefly outlines the basic ideas behind theories of localization and urbanization. ${ }^{7}$

\footnotetext{
${ }^{7}$ Although not directly relevant to the present study it may be instructive to conclude this section with a note on the so-called localization and urbanization static externalities. These static externalities explain how natural resources or transport advantage may determine the location of industries. They in turn contribute to specialization but not to growth. This is especially important for high-fixed-cost industries. There are also arguments against urbanization externalities. When an industry in a city grows it increases wages and rents and so makes it more expensive for other industries to expand in the city, this is referred to as crowding. Conversely, when an industry in a city shrinks it frees up land and labor and makes growth of other industries more attractive.
} 
In this section we will explore some of the more important empirical results. There have been a few empirical tests of the three theories of dynamic externalities. Glaeser et al. (1992) examine the predictions of the various theories of knowledge spillovers and growth using data on geographic concentration and competition of industries in 170 of the largest US cities. They chose the largest industries since one of the strongest implications of growth models is that externalities in these models are sources of permanent income growth. If, it is the case that these externalities are in fact permanent and important then one would expect to observe them in the largest industries. If, on the other hand, externalities are important only early in an industry's life cycle and disappear after an industry matures then they would not be picked up empirically, and this implies that they are not sources of permanent growth.

The first question asked by Glaeser et al. is which industries in which cities have grown fastest between 1956 and 1987 and why. Bearing in mind that the three theories of dynamic externalities differ in what they believe the source of externalities is and what makes their capture more effective. Testing empirically in which cities industries grow faster as a function of geographic specialization and competition would shed some light on which externalities if any are important for growth.

The empirical findings derived by Glaeser et al. is based on a cross section of city industries (e.g., New York apparel and textiles, Philadelphia apparel and textiles, Philadelphia electrical equipment). This facilitates tracing knowledge spillovers compared to if one were investigating whole cities. The first finding is that industries, measured by employment, grow slower in cities where they are over represented. This finding does not favor the local within-industry externality theory of MAR and Porter, according to which industries should grow faster in places where they are over represented. In addition, they also find that industries grow faster in cities where firms in those industries are smaller than the national average size of firms in that particular industry. If we take the view that spreading the same employment over more firms increases local competition between firms and therefore the spread of knowledge, then this result would support Porter's and Jacob's view that local competition is growth promoting. On the other hand, one could take the view that smaller firms grow faster, however, this is not completely compatible with the MAR model or with other evidence. Lastly they find that cityindustries grow faster when the rest of the city is less specialized. This result supports Jacobs's view that city diversity promoted growth as knowledge spills 
over industries. To summarize the empirical evidence found in this study does not support the MAR model, is mixed on Porter and is consistent with Jacobs.

One may wonder why are so many cities specialized in few industries if MAR externalities are not so important (at least in the previous empirical investigation they are not). The answer is that there are many other externalities not accounted for by theories of dynamic externalities that may explain regional specialization and city formation. These externalities do not consider knowledge spillovers and growth. Marshall (1980), for example, has argued that firms in the same industry often locate next to each other to share various inputs. ${ }^{8}$ Moreover, Henderson (1986) presents empirical evidence indicating that output per labor-hour is higher in firms that have other firms from the same industry located nearby. Static localization externalities can thus easily account for city specialization, but not for growth.

In addition, Henderson (1986) explained so-called "urbanization" externalities which explains why firms may chose to locate in places where demand is high. These models tend to predict that firms in different industries tend to locate next to each other, which suggests that they do not offer the complete story of city formation. Lichtenberg (1960), Murphy, Schleifer and Vishny (1989), and Krugman (1991a, 1991b) have presented models of such externalities. Urbanization externalities and localization externalities, thus, explain patterns of industry location rather than growth. Moreover, Wheat (1986) finds strong evidence that manufacturing employment grows faster in regions with more rapid population growth. Glaeser et al. also presented some evidence pointing toward the importance of urbanization externalities.

In Henderson (1994) additional empirical evidence on the role of dynamic externalities for individual industries is provided. In particular, the role of externalities from own industries (localization, or MAR externalities) as opposed to the role of externalities from overall diversity of the local environment (urbanization, or Jacobs externalities) is examined. Henderson employs panel data that allows to separate dynamic effects from fixed effects. Panel data analysis also provides evidence as to how long history matters. Two basic issues are tested, first whether firms learn primarily from other firms within an industry or from firms outside the industry, and second whether externalities of whatever type are primarily static or dynamic. Henderson uses an eleven-year panel for 1977-1987 of data on country employment levels in different 2-digit manufacturing industries.

${ }^{8}$ Other externalities are disscused by Lichtenberg (1960), Henderson (1986,1988), Arthur (1989), and Rotenberg and Saloner (1990). 
The basic finding derived by Henderson is that the maintenance of strength in a particular industry requires concentrations of employment in that industry and a surrounding diverse industrial base. Diversity, thus, tends to raise productivity and hence employment in a city's particular concentration activity. Moreover, the evidence suggests that both localization and urbanization effects are important. In other words there is evidence of both MAR and Jacobs externalities. For traditional industries most effects die out after four or five years, but for high tech industries effects can persist longer, that is history does matter according to Henderson (1993).

Jaffe et al. (1993) analyze the extent to which externalities are static or dynamic. Their work suggests that industry specific information diffuse slowly over space, so that access to that knowledge binds firms to the same location over time, however, this geographical localization fades away overtime. A larger scale of own industry activity historically means that firms today in a particular location will operate with greater intangibles, such as accumulated knowledge ${ }^{9}$ than otherwise. Moreover, the social information network of a certain location matters in facilitating communications and information spillovers among local firms.

From the above it is apparent that the existing tests have focused on the case of the US which, although instructive, is by no means general. Thus, more empirical tests of the various theories based on other case studies would be informative. In light of the above two issues can be empirically investigated. First, we can study whether there are differences in the relevance of the various theories of static and dynamic externalities based on country differences, and to what factors such differences could be attributed.

\section{Arriving to the Reduced Form}

The three theories of dynamic externalities, following Glaeser et al., can be combined in an economic model from which the reduced form can be derived. Assume that each firm in an industry at a given location takes technology, prices and wages as given and maximizes the following function:

$$
A_{t} f_{t}\left(l_{t}\right)-w_{t} l_{t}
$$

Where $A_{t}$ is technology measured nominally, ${ }^{10}$ is the basic production function,

\footnotetext{
${ }^{9}$ About technology, sources of supply of different quantity inputs, etc.

${ }^{10}$ Such that changes in $A$ represent changes in technology and in prices.
} 
$l_{t}$ is labor input, and $w_{t}$ is wages at time $t .{ }^{11}$ Each firm thus sets the labor input to equate the marginal product of labor to it's wage:

$$
A_{t} f^{\prime}\left(l_{t}\right)=w_{t}
$$

Rewriting (2) in terms of growth rates gives:

$$
\log \left(\frac{A_{t+1}}{A_{t}}\right)=\log \left(\frac{w_{t+1}}{w_{t}}\right)-\log \left[\frac{f^{\prime}\left(l_{t+1}\right)}{f^{\prime}\left(l_{t}\right)}\right]
$$

The level of technology $A_{t}$ in a city-industry is assumed to have both national and local components such that:

$$
A=A_{\text {local }} A_{\text {natinal }}
$$

The growth rate will thus be the sum of the growth of national and local technology in this industry such that.

$$
\log \left(\frac{A_{t+1}}{A_{t}}\right)=\log \left(\frac{A_{\text {local }, t+1}}{A_{\text {local }, t}}\right)+\log \left(\frac{A_{\text {natilnal }, t+1}}{A_{\text {national }, t}}\right)
$$

Growth in national technology is assumed to capture the changes in the price of the products as well as shifts in nationwide technology in the industry. Local technology is assumed to grow at a rate exogenous to the firm but dependent on the various technological externalities present in this industry in this city, that is:

$$
\log \left(\frac{A_{\text {local }, t+1}}{A_{\text {local }, t}}\right)=g(\text { specialization, localmonopoly, diversity, initialconditions })+e_{t+1}
$$

Where specialization is a measure of concentration of a particular industry within a city, which according to MAR and Porter is supposed to raise the rate of technological progress. Local monopoly is a measure of appropriability of innovation, which raises technological progress according to MAR and reduces it according to Porter; and diversity measures the variety of activities that the city pursues, which according to Jacobs speeds up technological progress. Initial values of wages and employment are included because it has been argued that firms move to low-wage areas, and because high initial values of employment may reduce employment growth.

If we set $f(l)=l^{1-\alpha}, 0<\alpha<1$, then (3), (5), and (6) can be combined to obtain:

\footnotetext{
${ }^{11}$ Since the production function abstracts from capital inputs, and allows only for labor input, that means that labor-saving technology will not be captured.
} 


$$
\begin{gathered}
\alpha \log \left(\frac{l_{t+1}}{l_{t}}\right)=-\log \left(\frac{w_{t+1}}{w_{t}}\right)+\log \left(\frac{A_{\text {national }, t+1}}{A_{\text {national }, t}}\right)+g(\text { specialization, competition, } \\
\text { diversity, initial conditions })+e_{t+1}
\end{gathered}
$$

Growth in nationwide employment is assumed to capture changes in nationwide technology and prices. Workers are assumed to participate in a nationwide labor market so that the wage growth will just be the same across city-industries. Equation (7) thus allows us to associate the growth of employment in an industry in a city with the measures of technological externalities given by the theories. ${ }^{12}$

\section{Data and Variable Description}

\section{A. The Data}

The data set was constructed from 1977 and 1996 editions produced by Swedish Statistical Bureau (SCB). 1977 and 1996 were the first and last years respectively for which comprehensive industrial statistics on a regional level was available. ${ }^{13}$

Three basic variables on employment, payroll and number of establishments by two-digit industry for every region in Sweden (a total of 24 regions) are utilized for the construction of the various proxies employed in the regression analysis. ${ }^{14}$

\section{B. Variable Description}

Following Glaeser et al. (1992) in the choice of variables and methodology, A Swedish data set was constructed and linear regressions are thereafter run ${ }^{15}$. The variables are described below:

\section{The Results}

The results of the initial regressions are reported in Table 1, where the seven

\footnotetext{
${ }^{12}$ The specification of (7) assumes that knowledge spillovers are constant over time, which a is basic restriction of the model.

${ }^{13}$ It ought to be noted that the period chosen is a rather special one for Sweden (as well as other countries) in terms of technological progress, I will return to this issue when discussing the results.

${ }^{14}$ The data employed is regional as opposed to city data.

${ }^{15}$ There is no a priori reason to expect non-linearity thus the choice of linear regression analysis.
} 


\section{Table 1}

\begin{tabular}{l}
$\begin{array}{l}\text { 1. Growth in regional industry employment measured as: Growth in Regional industry mploy- } \\
\text { ment measured as: log (employment in 1996/employment in 1977) in the regional industry. }\end{array}$ \\
\hline $\begin{array}{l}\text { 2. Growth in national industry employment measured as: log (employment in 1996/employ- } \\
\text { ment 1977) in the industry outside the region. }\end{array}$ \\
\hline $\begin{array}{l}\text { 3. Wages in the regional industry in } 1977 \text { in thousands of SEK per year, measured as: (payroll } \\
\text { in 1977/employment in 1977). }\end{array}$ \\
\hline 4. Regional industry employment in 1977. \\
\hline $\begin{array}{l}\text { 5. Specialization measured as: regional industry's share of regional employment relative to } \\
\text { National industry's share of National employment in 1977. }\end{array}$ \\
\hline $\begin{array}{l}\text { 6. Competition measured as: establishment per employee in the regional industry relative to } \\
\text { establishment per employee in the industry nationwide in 1977. }\end{array}$ \\
\hline $\begin{array}{l}\text { 7. Diversity measured as : the region's other top five industries share of 1977 total regional } \\
\text { employment. }\end{array}$ \\
\hline $\begin{array}{l}\text { 8. Growth in regional industry wages measured as: log (wage in 1996/wage in 1977) in the } \\
\text { regional industry. }\end{array}$ \\
\hline $\begin{array}{l}\text { 9. Growth in national industry wages measured as: log (national wage in 1996/national wage } \\
\text { 1977) in the industry outside the region. }\end{array}$ \\
\hline 10. Wage in the region in 1987. \\
\hline
\end{tabular}

largest industries in all 24 Swedish counties are included making a total of 168 observations. As control variables log employment in 1977 and log wages in 1977 both of can be regarded as initial conditions. Moreover, it has been argued that firms move to low wage regions, or that laborers move to high wage areas, thus the wage variable controls for this effect. Terkla and Doeringer (1991) and Blanchard and Katz (1992) suggest that changes in demand for a regions output are the principal determinants of employment growth in that region. Consequently, in order to correct for such demand shifts national employment growth in the industry is included as an explanatory variable.

The externality variables, i.e. specialization, competition and diversity are included separately in columns (i), (ii), and (iii) respectively. In column (iv) all three externality variables are included at the same time.

The results suggest that initial employment and wages, or the initial conditions, are not significant. Growth in national employment, as may be expected, is significant at the $1 \%$ level and is quantitatively high varying between 1.015 and 0.986. Of the three externalities only Competition seems to affect industry growth and is significant at the $10 \%$ level when included separately in column (ii) and 
Table 2. Regression Results

Dependent Variable Regional Industry Employment Growth between 1977-1996 for the seven largest industries

\begin{tabular}{|l|l|l|l|l|}
\hline \multicolumn{1}{|c|}{ Variables } & (i) & (ii) & (iii) & (iv) \\
\hline \multirow{3}{*}{ Constant } & 0.185 & 0.034 & 0.184 & 0.079 \\
& $(0.51)$ & $(0.09)$ & $(0.49)$ & $(0.22)$ \\
& {$[0.61]$} & {$[0.92]$} & {$[0.62]$} & {$[0.82]$} \\
\hline \multirow{3}{*}{ Log employment 77 } & 0.020 & 0.063 & 0.019 & 0.058 \\
& $(0.37)$ & $(1.18)$ & $(0.33)$ & $(1.02)$ \\
& {$[0.71]$} & {$[0.24]$} & {$[0.74]$} & {$[0.31]$} \\
\hline & -0.150 & -0.186 & -0.146 & -0.183 \\
Log wage 77 & $(-0.63)$ & $(-0.81)$ & $(-0.58)$ & $(-0.77)$ \\
& {$[0.53]$} & {$[0.42]$} & {$[0.56]$} & {$[0.44]$} \\
\hline \multirow{2}{*}{ National employment } & 1.013 & 0.986 & 1.011 & 1.015 \\
Growth in the industry & $(8.03)^{* * *}$ & $(8.52)^{* * *}$ & $(8.12)^{* * *}$ & $(8.34)^{* * *}$ \\
& {$[0.00]$} & {$[0.00]$} & {$[0.00]$} & {$[0.00]$} \\
\hline \multirow{3}{*}{ Specialization } & 0.001 & & & 0.006 \\
& $(0.12)$ & & & $(1.12)$ \\
\hline \multirow{2}{*}{ Competition } & {$[0.91]$} & & & {$[0.26]$} \\
& & 0.062 & & 0.071 \\
& & $(1.6)^{*}$ & & $(1.71)^{*}$ \\
Diversity & & {$[0.10]$} & & {$[0.09]$} \\
\hline OBS. & & & -0.008 & -0.067 \\
\hline $\bar{R}^{2}$ & 168 & 168 & $(-0.04)$ & $(-0.33)$ \\
\hline
\end{tabular}

Note: parenthesis ( ) give heteroscedasticity consistent $t$-statistics, and [ ] give p-values. $*=$ significant at the $10 \%$ level $* *=$ significant at the $5 \%$ level, and $* * *=$ significant at the $1 \%$ level.

when included together with specialization and diversity, in column (iv). However, specialization and diversity do not seem to explain regional industry employment growth. The coefficient for competition varies between $0.06-0.07$ this suggests that doubling the number of firms per worker compared to the national average leads to between 6-7\% increase regional employment over a period of twenty years.

To interpret the results taking the theoretical background as a point of departure requires a brief recapitulation of the three theories of dynamic externalities. As mentioned above both MAR and Porter share the view that regional specialization is good for growth. Nevertheless, MAR argues, contrary to Porter and Jacobs who prefers local competition, that local monopoly is good because it internalizes 
Table 3. Regression Results Dependent

Variable Regional Industry Wage Growth between 1977-1996, for the six largest industries

\begin{tabular}{|c|c|c|c|c|}
\hline Variables & (i) & (ii) & (iii) & (iv) \\
\hline Constant & $\begin{array}{l}2.021 \\
(3.06)^{* * * *} \\
{[0.00]}\end{array}$ & $\begin{array}{l}2.139 \\
(3.17)^{* * * *} \\
{[0.00]}\end{array}$ & $\begin{array}{l}2.039 \\
(2.99)^{* * *} \\
{[0.003]}\end{array}$ & $\begin{array}{l}2.133 \\
(3.21)^{* * * *} \\
{[0.001]}\end{array}$ \\
\hline Log employment 77 & $\begin{array}{l}-0.023 \\
(-0.99) \\
{[0.32]}\end{array}$ & $\begin{array}{l}-0.046 \\
(-1.46) \\
{[0.14]}\end{array}$ & $\begin{array}{l}-0.019 \\
(-0.75) \\
{[0.45]}\end{array}$ & $\begin{array}{l}-0.042 \\
(-1.41) \\
{[0.16]}\end{array}$ \\
\hline Log wage 77 & $\begin{array}{l}-0.862 \\
(-2.08)^{* *} \\
{[0.04]}\end{array}$ & $\begin{array}{l}-0.849 \\
(-2.19)^{* *} \\
{[0.028]}\end{array}$ & $\begin{array}{l}-0.862 \\
(-2.06)^{* *} \\
{[0.04]}\end{array}$ & $\begin{array}{l}-0.873 \\
(-2.23)^{* *} \\
{[0.02]}\end{array}$ \\
\hline $\begin{array}{l}\text { National wage growth } \\
\text { in the industry }\end{array}$ & $\begin{array}{l}0.464 \\
(0.99) \\
{[0.32]}\end{array}$ & $\begin{array}{l}0.449 \\
(1.05) \\
{[0.29]}\end{array}$ & $\begin{array}{l}0.413 \\
(0.91) \\
{[0.36]}\end{array}$ & $\begin{array}{l}0.446 \\
(1.01) \\
{[0.31]}\end{array}$ \\
\hline Specialization & $\begin{array}{l}0.005 \\
(1.37) \\
{[0.17]}\end{array}$ & & & $\begin{array}{l}0.003 \\
(0.77) \\
{[0.44]}\end{array}$ \\
\hline Competition & & $\begin{array}{l}-0.047 \\
(-1.17) \\
{[0.24]}\end{array}$ & & $\begin{array}{l}-0.044 \\
(-1.07) \\
{[0.28]}\end{array}$ \\
\hline Diversity & & & $\begin{array}{l}0.008 \\
(0.09) \\
{[0.93]}\end{array}$ & $\begin{array}{l}0.049 \\
(0.46) \\
{[0.64]}\end{array}$ \\
\hline$O B S$. & 144 & 144 & 144 & 144 \\
\hline $\bar{R}^{2}$ & 0.13 & 0.15 & 0.13 & 0.14 \\
\hline
\end{tabular}

Note: parenthesis ( ) give heteroscedasticity consistent $t$-statistics, and [ ] give p-values. ${ }^{*}=$ significant at the $10 \%$ level $* *=$ significant at the $5 \%$ level, and $* * *=$ significant at the $1 \%$ level.

externalities. Finally, Jacobs claims that the crucial externality in cities is crossfertilization of ideas across different industries, and like Porter Jacobs favors local competition because it stimulates innovation.

Thus, the MAR theory was not supported by the above evidence, however, neither was it rejected. In particular, in equations (i) and (iv) the coefficient for the specialization variable was not significant in either case suggesting that the evidence is inconclusive. Neither did Jacobs claim that the variety of neighboring industries enhances growth receive conclusive support. In both equations (iii) and (iv) the variable measuring diversity was insignificant. However, Jacobs' and Porter's suggestion that more firms per worker in a city-industry compared with the national average, or competition, would lead to higher growth seems to receive empirical support. The evidence from equations (ii) and (iv) reveals that the 
competition variable is positive and significant and is, thus, consistent with both Porter's and Jacobs' theories of dynamic externalities. ${ }^{16}$

Following Glaeser et al. I have, thus far, measured industry growth using employment growth a better measure is naturally productivity growth. However, since output is non-observable it is difficult to measure productivity. On the other hand, it is plausible that a rough measure of productivity growth may be cityindustry wage growth, assuming that some of the productivity gains accrues to labor. The same procedure described above is employed here, i.e. the three externalities are included separately in the first three columns and in the last regression all three are included. The results are presented in Table 3 below.

From the Table above some basic observations can be made, to begin with only the logarithm of wages in 1977 seems to matter for the growth in regional industry wages between 1977 and 1996. Moreover, none of the three dynamic externalities seems to affect regional industry wage growth although some weak evidence is found for specialization. Finally neither the logarithm for employment nor national wage growth in the industry seems to matter for regional industry wage growth, or at the very least the evidence is inconclusive.

There is more than one explanation for the week evidence presented above. To begin with the measure used here to proxy productivity growth is not compatible with the model of national labor markets presented above. In addition, since productivity growth only accrues partially to labor measuring it with growth in wages is rather imperfect. ${ }^{17}$ Nevertheless since I took Glaeser et al. as my point of departure the basic aim has been to compare their results with the ones derived here on Swedish data. Consequently despite the problems associated with the cityindustry wage growth measure I thought it would be informative to run these regressions on the Swedish data.

Due to the reliance on proxy variables specification tests are called for. Therefore I performed the Ramsey (1969) test of omitted variables and the null hypothesis of no contemporaneous correlation could not be rejected at the $5 \%$ level. The interpretation being that omitted variables need not be an important problem in the

\footnotetext{
${ }^{16}$ The very same regressions were run employing the largest six, instead of the largest seven. As might be expected the results were upheld when using the largest six instead of seven industries. The variables that seem to matter for industry growth, measured by employment growth are growth in national employment and competition. Thus the results are still consistent with parts of Porters and Jacobs' hypothesis.

${ }^{17}$ Additional discussion can be found in Glaeser et al. (1992).
} 
analysis. I have also conducted a normality test according to Shapiro and Wilk (1965), and the hypothesis of normality could not be rejected at the 5\% level. Suggesting that the OLS estimations are consistent and efficient. Needless to say that despite these tests the results ought to be considered with caution. ${ }^{18}$

\section{Swedish versus American Industrial Growth: An Appraisal}

Prior to further discussion some relevant potential concerns to the results need to be pointed out. There are two basic reservations that can be of relevance for both this study and Glaeser et al. To begin with, the fact that the production function does not allow us to capture labor saving technological innovations, and that the dependent variable measures growth in employment at a period where labor-saving technological progress is certainly actual. The second reservation is the inclusion of the initial employment values, making the model specification seem more like an endogenous growth model as implied by the inclusion, this in turn makes inferences about location questionable.

Having stated this let us now look more carefully at the Swedish as compared to the American results bearing in mind the above mentioned reservations. In the American case competition and urban variety seemed to explain employment growth in industries within metropolitan areas. Whereas in the Swedish case only competition seemed to explain employment growth in industries in Swedish regions. The fact that local competition is the most important dynamic externality in Sweden can be attributed to the fact that Swedish industries have for a long time been regulated. At least in relative terms the Swedish industrial environment is less competitive compared to the American. This can be attributed to various factors among which protection and militant labor unions in Sweden are certainly accountable. Nonetheless, the evidence suggests that competition is important even in the American case, that is indicative of the importance of this type of externality in general for industrial growth.

The evidence does not necessarily suggest that urban variety and regional specialization are not important in Sweden, they may very well be but not to the same extent as local competition. From the evidence presented in this study the variables capturing urban variety and regional specialization turn out insignificant or inconclusive. Compared to the American case where urban variety as suggested by Jacobs enhances industrial growth. One may thus conclude that urban variety is

\footnotetext{
${ }^{18}$ Diagnostic testing have a rather low power and are thus difficult to reject.
} 
more important in the US than it is in Sweden. This in turn may be attributed to differences in the nature of industrial dispersion in the two countries, which in turn is a consequence of very different geographical characteristics and economic sizes of Sweden compared to the US.

A basic distinction to which some econometric complications may be attributed is the distinction between dynamic and static externalities. The latter is by definition continuos while the former is static. Thus, the lack of robust econometric results might be due to the fact that dynamic effects at least in some cases are only temporary; i.e. change from one level to the other. In which case their effect could not be captured by the specified estimation. ${ }^{19}$ According to the reduced form estimated, the specification assumes that the proxies for dynamic externalities are flow variables. Thus, any temporary changes from one level to the other would not be captured and rendered statistically insignificant coefficients.

The reliance on proxy variables in the econometric estimations represents an additional problem. Unfortunately it is not uncommon to rely on surrogate variables or so-called proxy variables in econometric estimations. This is due to the fact that some variables are very difficult to quantify especially intangible variables such as those employed in the present study. Naturally this may be argued as a weakness, nevertheless, it is by all means not a weakness that makes the estimations inconsistent only inefficient. Thus, some caution is recommended when drawing conclusions based on estimations that make use of proxy variables.

Furthermore, worth noting is that the differences in the results may partially be attributed to the choice of time periods which are different in the two studies. In Glaeser et al. the time period employed was 1956-1987, whereas in the present study I employ $1977-1996^{20}$. In particular, the time period employed for Sweden case is characterized by relevant developments. To begin with, technological development combined with a slow productivity trend in Swedish industries during that period led to reduced employment in virtually all industries. Secondly the deregulation of Swedish industries which coincided with this period are also expected to affect the results. In the latter case, however, we would expect deregulation to bias the results in the opposite direction making competition less important and or insignificant. In

\footnotetext{
${ }^{19}(7) \alpha \log \left(\frac{l_{t+1}}{l_{t}}\right)=-\log \left(\frac{w_{t+1}}{w_{t}}\right)+\log \left(\frac{A_{\text {national }, t+1}}{A_{\text {national }, t}}\right)+g($ specialization, competition, diversity, initial conditions) $+e_{t-1}$

${ }^{20}$ For which regional industrial data was available.
} 
other words, the fact that competition seems to be the only important externality for industrial growth in Sweden, despite deregulation, implies that further deregulation may be important for industrial growth in the Swedish case.

Thus, if we were to draw policy implications based on the Swedish evidence it would be a policy which aims at deregulation of Swedish industries. Since local competition is the only statistically significant variable explaining industrial growth then it is fair to draw the conclusion that policies aimed at enhanced local competition are most likely to be growth promoting.

\section{Concluding Remarks}

In general we can conclude, with some reservation, that the relevance of the three theories of dynamic externalities does vary according to country differences. This in turn may be explained by the differences in the economic environments of different countries. In particular, comparing the US case with the Swedish case gave interesting insights in this regard. Whereas in the American case local competition and urban variety could explain employment growth in industries, in the Swedish case local competition appeared to be the most important for industry growth. The explanation to the above is two fold, on the one hand there are differences associated with the geographical natures of the American compared to the Swedish economies, on the other hand there may econometric concerns due to the reliance on proxy variables.

This study by all means suggests the need for further empirical research to add to our understanding of how theories of dynamic externalities work in practice. In this regard additional country studies of a similar nature to this one would be instructive. Secondly, it would be interesting to see whether the theories are more or less relevant for different industries. Whether for example Jacob's theory is more applicable for the car industry as compared with the computer industry which in turn may better be explained by the MAR theory. Furthermore, the construction of new variables and data sets on the industry level would by all means facilitate further research in this relatively new area.

Received May 2002, Accepted 17 February 2003

\section{References}

Arrow, K. J., (1962), “The Economic Implications of Learning by Doing”, Review of 
Economics Studies, 29, 155-73.

Arthur, W. B. (1989), "Silicon Valley Locational Clusters: When Do Increasing Returns Imply Monopoly?", working paper, Santa Fe, N.M., Santa Fe Institution.

Bairoch, P. (1988), Cities and Economic Development: From the Dawn of History to the Present, Chicago: Chicago University Press.

Blanchard O. J. and L. F. Katz, (1992), "regional Evolutions", Brookings Papers Econ. Activity, no.1.

Glaeser E. L., H. D. Kallal, J. A. Scheinkman and A. Schleifer, (1992), "Growth in Cities", Journal of Political Economy, 100(6), 1126- 1152.

Henderson, J. V. (1986), "Efficiency of Resource Usage and City Size", Journal of Urban Economics, 19, 47-70.

Henderson, J. V. (1988), Urban Development: Theory, Fact, and Illusion, New York: Oxford University Press.

Henderson, J. V. (1994), "Externalities and Industrial Development", NBER Working Paper No. 4730.

Henderson, J. V. A. Kuncoroand and M. Turmer, (1992), "Industrial Development in Cities", NBER Working Paper No. 4178.

Herzog, H. W. and A. M. Schlottman, (1991), (eds.), Industrial Location and Public Policy, Knoxville: University of Tennessee Press.

Jacobs, J. (1969), The Economy of Cities, New York: Vintage.

Jaffe, A. B. M. Trajtenberg and R. Hendersson, (1993), "Geographical Localization of knowledge spillovers as evidenced by Patent Citations", Quarterly Journal of Economics, 577-598.

Krugman, P. (1991a), "Cities in Space: Three Simple Models", Manuscript, Cambridge: MIT.

Krugman, P. (1991b), "Increasing Returns and Economic Geography", Journal of Political Economy, 99, 483-99.

Lichtenberg, R. M. (1960), One-Tenth of a Nation: National Forces in the Economic Growth of the New York Region, Cambridge, Mass.: Harvard University Press.

Lucas, R. E., Jr. (1988), "On the Mechanics of economic Development", Journal of Monetary Economics, 22, 3-42

Marshall, A., (1890), Principles of Economics, London: Macmillan.

Miracky, W. F. (1992), "Technological Spillovers, the Product cycle and Regional Growth", MIT mimeo.

Murphy, Shleifer and Vishny.

Porter, M. E. (1990), The Competitive Advantage of Nations. New York: Free Press.

Ramsey, J.B. (1969), "Tests for Specification Errors in Classical Linear Least Squares Regression Analysis", Journal of The Royal Statistics Society, Series B, 31, 350-371.

Romer, P. M. (1986), "Increasing Returns and Long-Run Growth", Journal of Political Economy, 94, 1002-37.

Rotemberg J. and G. Saloner, (1990), "Competition and Human Capital Accumulation: A theory of Interregional

Shapiro, S. S. and Wilk, M. B. (1965). "An Analysis of Variance Test for Normality", 
Biometrika 52(4), 591-611.

Specialization and Trade, Manuscript, Cambridge MIT.

Schumpeter, J. A. (1942), Capitalism, Socialism, and democracy, New York: Harper.

Wheat, L. F. (1986), “The Determinants of 1963-77 Regional Manufacturing Growth:

Why the South and West Grow", Journal of Regional Science, 26, 635-59.

Terkla, D. G. and P. B. Doeringer, (1991), "Explaining Variations in Employment Growth: Structural and Cyclical Change among States and Local Areas", Journal of Urban Economics, 29, 329-48.

\section{Appendix I}

Table I. Summary Statistics

\begin{tabular}{llrrrr}
\hline \multicolumn{1}{c}{ Series } & Obs & \multicolumn{1}{c}{ Mean } & \multicolumn{1}{c}{ Std Error } & \multicolumn{1}{c}{ Minimum } & \multicolumn{1}{c}{ Maximum } \\
\hline CEMPLGROWTH & 168 & -0.173931 & 0.222708 & -1.104198 & 0.468355 \\
NEMPLGROWTH & 168 & -0.150643 & 0.120957 & -0.656469 & 0.043731 \\
LOGWAGE77 & 168 & 1.851316 & 0.053449 & 1.532283 & 2.028048 \\
LOGEMPL77 & 168 & 3.498876 & 0.384960 & 2.133539 & 4.528788 \\
CWAGES77 & 168 & 71.522127 & 8.363579 & 34.062970 & 106.671390 \\
CITYEMPL77 & 168 & 4460.321429 & 4253.316238 & 136.000000 & 33790.000000 \\
SPECIALIZATION77 & 168 & 1.574063 & 1.651847 & 0.253778 & 19.211183 \\
COMPETITION77 & 168 & 1.028106 & 0.527404 & 0.098120 & 2.968896 \\
DIVERSITY77 & 168 & 0.708170 & 0.084157 & 0.460485 & 0.878340 \\
CWAGEGROWTH & 168 & 0.660339 & 0.252501 & -0.176177 & 2.614496 \\
NWAGEGROWTH & 168 & 0.630489 & 0.017179 & 0.606379 & 0.685096 \\
\hline
\end{tabular}

\section{Appendix II}

Table II. a. Largest Regional Industries in 1977 (Sweden)

\begin{tabular}{llc}
\hline \multicolumn{1}{c}{ Region } & \multicolumn{1}{c}{ Industry } & Employment \\
\hline 1 Älvsborgs & Transport Equipment (vehicles, ships, Aerospace, other) & 33,790 \\
2 Stockholm & Electric and optical equipment & 26,236 \\
3 Skaraborgs & Textiles, wearing apparel, fur and leather & 18,258 \\
4 Stockholm & Pulp, paper, paper products, publishing, printing and & 16,161 \\
& reproduction of recorded media & \\
5 Hallands & Food, beverages and tobacco & 13,338 \\
6 Skaraborgs & Transport Equipment (vehicles, ships, Aerospace, other) & 12,465 \\
7 Kopparbers & Electric and optical equipment & 11,291 \\
8 Västerbottens & Basic metals & 11,126 \\
9 Stockholm & Transport Equipment (vehicles, ships, Aerospace, other) & 10,426 \\
10 Västermanslands & Machinery & 10,284 \\
\hline
\end{tabular}


Table II. b. Most Common Regional Industries (Sweden)

\begin{tabular}{lc}
\hline \multicolumn{1}{c}{ Industry } & Number of Appearances in Sample \\
\hline Fabricated metal products & 22 \\
Machinery & 22 \\
Pulp, paper, paper products, publishing, printing and & 21 \\
reproduction of recorded media & \\
Food, beverages and tobacco & 17 \\
Wood and cork & 15 \\
Transport equipment & 12 \\
Basic metals & 10 \\
Coke, refined petroleum products \& nuclear feul, & 8 \\
Chemical \& chemical products & \\
Electronic machinery, electronic equipment Medical & 7 \\
precision \& optical instruments, watches clocks & \\
Non-metallic mineral products (stone, clay, \& glass) & 5 \\
\hline
\end{tabular}

